\title{
ISOLATION, MOLECULAR IDENTIFICATION AND CHARACTERIZATION OF BORON-TOLERANT BACTERIAL STRAINS FROM SEWAGE TREATMENT POND OF ISLAMABAD, PAKISTAN
}

\author{
JAVED, R. ${ }^{1,2^{*}}-$ AHMED, I. $^{1 *}-$ KHALID, N. ${ }^{3}-$ IQBAL, M. ${ }^{4}$ \\ ${ }^{1}$ Institute of Microbial Culture Collection of Pakistan (IMCCP), National Agricultural Research \\ Centre (NARC), Park Road, Islamabad 45500, Pakistan \\ ${ }^{2}$ Department of Biotechnology, Faculty of Biological Sciences, Quaid-i-Azam University \\ Islamabad 45320, Pakistan \\ ${ }^{3}$ School of Food and Agricultural Sciences, University of Management and Technology \\ Lahore 54000, Pakistan \\ ${ }^{4}$ National Institute of Genomics and Advanced Biotechnology (NIGAB), National Agricultural \\ Research Centre (NARC), Park Road, Islamabad-45500, Pakistan \\ *Corresponding authors \\ e-mail: iftikharnarc@hotmail.com; rabia.javed@ymail.com \\ (phone: +92-51-9073-3729; fax: +92-51-9255-034) \\ (Received 27 ${ }^{\text {th }}$ Apr 2017; accepted $1^{\text {st }}$ Aug 2017)
}

\begin{abstract}
Boron-tolerant bacteria fall in the category of extremophilic organisms as they have the ability to survive in high boron environments. Such bacterial species needs to be characterized to identify new extremophilic organisms from the ecology for biotechnological benefits. In this study, five boron-tolerant bacterial strains, designated as NCCP-132, NCCP-133, NCCP-134, NCCP-135 and NCCP-136 were isolated from sewage sludge treatment pond of Islamabad, Pakistan. These strains grew on media containing 200 to more than $450 \mathrm{mM}$ of boron concentration. However, the microbial growth is found high at low boron concentration. The isolated boron-tolerant bacterial strains were either extremely boron-tolerant or moderately boron-tolerant. The $16 \mathrm{~S}$ rRNA gene sequences and phylogenetic analyses delineated that all strains were found to be closely related to species belonging to different genera: Bacillus, Oceanobacillus and Lentibacillus. Strains NCCP-132, NCCP-134 and NCCP-135 are found to be novel species, while NCCP-133 and NCCP-136 are revealed to be previously identified bacterial species. Morphological, physiological and biochemical characteristics of these strains were studied at their optimal growth conditions. Our study inferred that the sewage treatment pond of Islamabad, Pakistan is rich in boron-tolerant extremophilic bacterial population with diverse bacterial communities having a potential to be utilized in various biotechnological applications in future.
\end{abstract}

Keywords: boron, $16 S$ rRNA, phylogeny, Bacillus, Lentibacillus, Oceanobacillus

\section{Introduction}

Boron is concentrated in the earth's crust in the form of borate minerals. The largest known boron deposits have been found in Turkey (Col and Col, 2003). Microbes, plants and animals require boron as micronutrient for their growth (Stanier et al., 1966; Goldbach et al., 2010), but the level of required concentration varies among different organisms (Saleem et al., 2011). Boron in lesser concentration has been declared useful for the treatment of candidal vulvovaginitis (Swate and Weed, 1974; Otero et al., 2002), food preservation against different microbes (Nielsen, 2004), and an insecticide against cockroaches (Cochran, 1995). Although boron is an essential micronutrient but a very 
narrow range exists between its sufficiency and toxicity (Nable et al., 1997). Boron toxicity to microbes, plants and animals usually cause growth retardation and deleterious effects on reproductive functions (Col and Col, 2003). In contrary, boron essentiality has been considered good for growing specific types of bacteria such as Bacillus boroniphilus (Ahmed et al., 2007a).

Extremophilic organisms possess great capacity to inhabit hostile conditions of salinity, drought, temperature, radiation, etc. (Rampelotto, 2010). During the last decade, boron toxicity has been studied as a new frontier in extremophiles and several novel species have been reported as tolerant to toxic concentrations of boron (Ahmed et al., 2007a, 2007b, 2007c, 2007d). Few bacterial species like Bacillus boroniphilus, Gracilibacillus boraciitolerans, Chimaereicella boritolerans, Lysinibacillus boronitoleran, Variovorax boronicumulans, Lysinibacillus parviboronicapiens, have shown various levels of boron tolerance (Ahmed et al., 2007a, 2007b, 2007c, 2007d; Miwa et al., 2008, 2009). Bacillus boroniphilus can tolerate $>450 \mathrm{mM}$ of boron but also it is reported to require boron for its normal growth. Some strains are reported to accomulate boron in their cells (Miwa et al., 2008, 2009) and found to be comparatively low in boron-tolerance. Boron-tolerant bacterial species maintain lower boron concentration in cells by an efflux mechanism (Ahmed and Fujiwara, 2010). These findings can be exploited for their applications in biotechnology.

Boron-tolerant bacteria needs to be explored in different ecologies worldwide, such as in salt mines and sewage treatment ponds. The objective of current study was to isolate and identify novel boron-tolerant bacterial strains from Pakistani ecology. These studies comprised of isolation and identification of boron-tolerant bacteria using $16 \mathrm{~S}$ rRNA gene sequencing, and their phenotypic characteristics including morphological, physiological and biochemical characterization. The findings of these studies may provide useful information for basic and applied sciences under extreme conditions of elemental boron toxicity.

\section{Materials and methods}

\section{Sample Collection}

Samples for isolation of boron-tolerant bacterial strains were collected in sterile bottles from sewage treatment pond of Sector I-9/1, Islamabad, Pakistan (location is shown in Figure 1) and then stored at $4^{\circ} \mathrm{C}$ until isolation of strains.

\section{Isolation and Enrichment}

Procedures of isolation and enrichment of cultures were performed to recover borontolerant bacterial strains on tryptic soy agar (TSA, Difco ${ }^{\mathrm{TM}}$ ) medium. Serial dilution of samples was carried out in phosphate buffer saline (PBS) in an appropriate volume. The diluted samples were streaked on TSA medium containing $50 \mathrm{mM}$ boron and incubated at $28{ }^{\circ} \mathrm{C}$ for 2-3 days. Isolated strains were sub-cultured many times under similar conditions. Later on, the pure cultures of morphologically different bacteria were obtained and used for further characterization. All of isolated strains were preserved at 4 ${ }^{\circ} \mathrm{C}$, and also in glycerol $(35 \% \mathrm{w} / \mathrm{v})$ stocks at $-80{ }^{\circ} \mathrm{C}$. 


\section{Growth Optimization}

Growth conditions of isolated strains were evaluated at different $\mathrm{pH}$ (4.0-10.0), temperature $\left(4-50{ }^{\circ} \mathrm{C}\right)$, and $\mathrm{NaCl}[0-16 \%(\mathrm{v} / \mathrm{v})]$ by allowing bacterial strains to grow in a shaking incubator at $28{ }^{\circ} \mathrm{C}$ for 2-5 days. TSB medium was used for optimization of growth conditions at $\mathrm{OD}_{600}$.

\section{Morphological Observation}

Morphological observations and comparisons were made using microbiological standard. Bergey's manual was used to characterize pure bacterial colonies on the basis of color, shape, margin, elevation, texture, size, etc. Gram staining and visualization of colony morphology of pure bacterial strains was done by light microscope (Nikon E600, Japan).

\section{Boron-tolerance Assay}

Boron-tolerance of each strain was performed by growing the bacterial strains at 28 ${ }^{\circ} \mathrm{C}$ in a shaking incubator using tryptic soy broth (TSB; Bacto ${ }^{\mathrm{TM}}$ ) medium containing various concentrations of boron from $0-450 \mathrm{mM}$. Bacterial growth was evaluated using spectrophotometer at $600 \mathrm{~nm}\left(\mathrm{OD}_{600}\right)$ for 3-7 days.

\section{Identification using 16S rRNA Gene Sequencing}

Genomic DNA extraction was performed following Ahmed et al. (2007a). It involved suspension of 2-3 well isolated bacterial colonies in $20 \mu \mathrm{L}$ of Tris EDTA (TE) buffer in a micro-PCR tube. After heating the cells at $95{ }^{\circ} \mathrm{C}$ for $10 \mathrm{~min}$, centrifugation was carried out at $6000 \mathrm{rpm}$ for 2-3 min. The pellet was discarded and the supernatant obtained was used as a template DNA for amplification of 16S rRNA gene. Polymerase chain reaction (PCR) was performed using 9F (5'-GAGTTTGATCCTGGCTCAG-3') and 1510R (5'-GGCTACCTTGTTACGA-3') primers and PreMix ExTaq (Takara, Japan) to amplify the $16 \mathrm{~S}$ rRNA gene of the isolated strains according to previous protocol (Ahmed et al., 2007a) using ABI Veriti PCR Machine (Applied Biosystems, USA) with the optimized PCR program, i.e., initial denaturation at $94{ }^{\circ} \mathrm{C}$ for $2 \mathrm{~min}, 30$ cycles of denaturation at $94{ }^{\circ} \mathrm{C}$ for $1 \mathrm{~min}$, annealing at $50{ }^{\circ} \mathrm{C}$ for $1 \mathrm{~min}$, extension at 72 ${ }^{\circ} \mathrm{C}$ for $1: 30 \mathrm{~min}$, and final extension at $72{ }^{\circ} \mathrm{C}$ for $5 \mathrm{~min}$. Amplification of $16 \mathrm{~S}$ rRNA gene was confirmed on $0.8 \%$ agarose gel. Documentation system (UVIPro Platinum, England) was used for viewing the DNA image. The purification and sequencing of amplified PCR products was performed using 27F (5'AGAGTTTGATCMTGGCTCAG-3') and 1492R (5'-ACCTTGTTACGACTT-3') primers and commercial service of Macrogen Inc. Korea (www.dna.macrogen.com).

\section{Phylogenetic Analysis}

Sequences were aligned using Clustal X software and the fragment sequences of $16 \mathrm{~S}$ rRNA gene were assembled by BioEdit. Later on, 16S rRNA gene sequences were submitted to DDBJ (http://www.ddbj.nig.ac.jp/) (Table 1). Bacterial strains were identified by BLAST search using $16 \mathrm{~S}$ rRNA gene sequences. Ez-Taxon server was used to retrieve the sequences of closely related type strains in order to construct phylogenetic trees. MEGA software Version 7 was used for phylogenetic and molecular evolutionary analyses. 


$$
-1214-
$$

\section{Biochemical Characterization}

Biochemical analysis of the isolated strains was performed using API ZYM, API 20E and API 50CH (bioMérieux, France) according to the manufactured protocols, whereas oxidase and catalase tests were performed according to the procedure of Cowan and Steel (2004). The suspension medium of API was utilized for inoculation of strips in all tests. API ZYM test was conducted for elucidation of enzymatic activities, and API $50 \mathrm{CH}$ strips were used for carbohydrate utilization and other biochemical analysis.

\section{Results and Discussion}

\section{Isolation and Identification of Boron-tolerant Bacteria}

The bacterial strains isolated from sewage treatment pond (shown in Figure 1) were found extremely and moderately boron-tolerant (tolerated up to $450 \mathrm{mM}$ of boron). This site was selected for sampling because it is reported that sewage treatment ponds are rich in bacteria that can grow in environment having high concentrations of boron element. A total of five bacterial strains were isolated because it is recommended that the number of strains studied for each taxon should be at least five, and ideally ten or more; observations on a minimum of three strains are necessary to have some indication of natural variability (Logan et al., 2009). This difference in strains could be due to the environmental changes occurring in different sites of the sewage treatment pond.

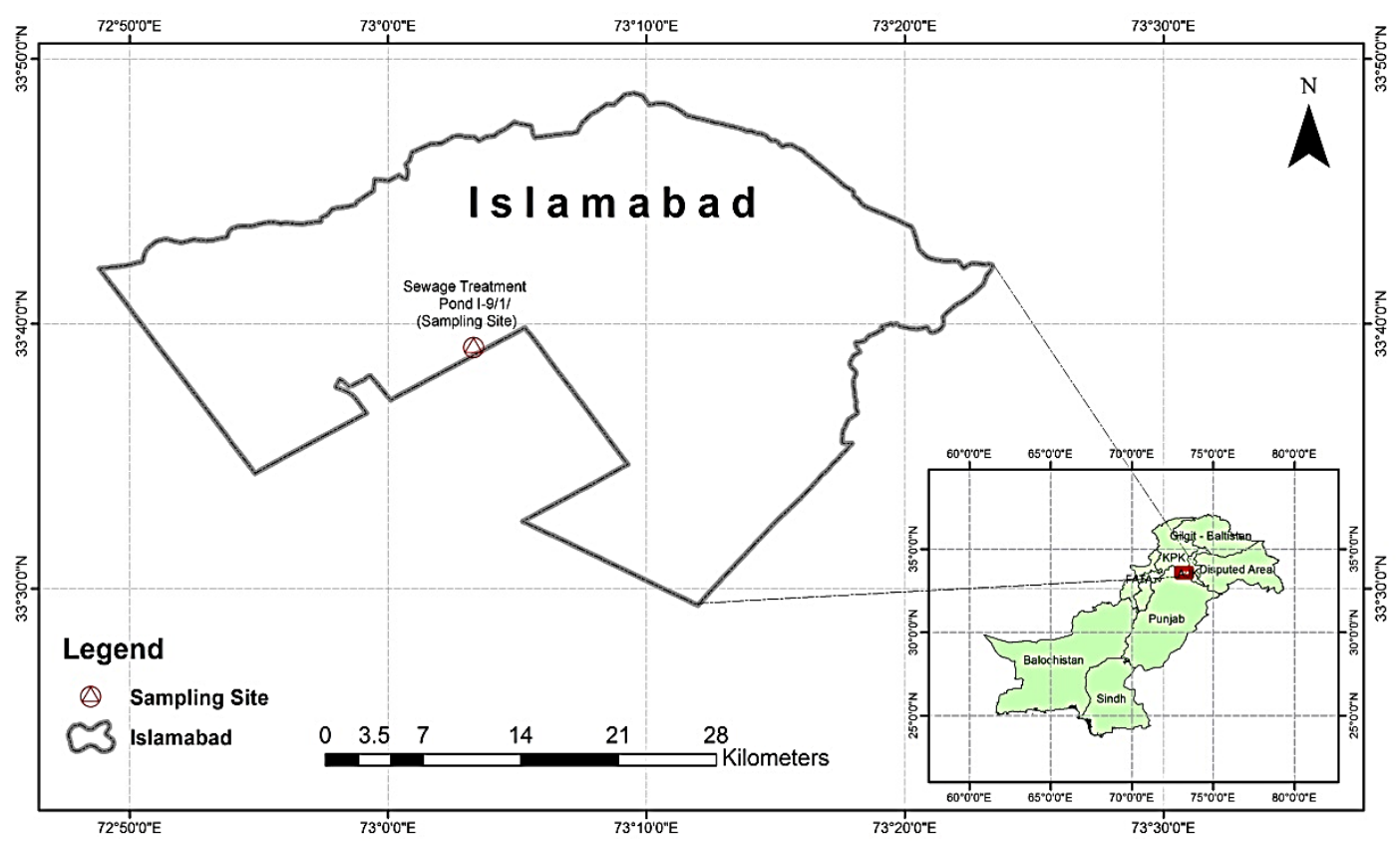

Figure 1. Map of Pakistan showing sampling site of Islamabad.

Taxonomic identification of five bacterial isolates was conducted by using the robust method of $16 \mathrm{~S}$ rRNA gene sequencing (Table 1). Thereafter, the phylogenetic position of each strain was determined by the construction of phylogenetic trees (Figures 1 and 2). Phylogenetic analysis delineated that the isolated strains belonged to Virgibacillus, Oceanobacillus, and Bacillus (Table 1). Two out of five strains (belonging to genus 
Bacillus) shared $>97 \%$ identity with their closest phylogenetic relatives. These result showed that NCCP-133 and NCCP-136 may belong to the known species of Bacillus

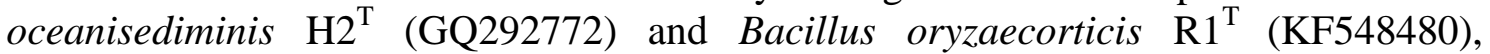
respectively, whereas the other three strains (belonging to genera Bacillus, Virgibacillus and Oceanobacillus) sharing $<97 \%$ sequence similarity confirmed that these strain belong to new species, however further taxonomic characterization experiments need to be performed to delineate these strains as novel species.

Table 1. Identification of isolated boron-tolerant bacterial strains based on 16S rRNA gene sequence and their accession numbers published in DNA database.

\begin{tabular}{|c|c|c|c|c|c|}
\hline Strain ID & Strain / Genus & $\begin{array}{c}\text { No. of } \\
\text { nucleotid } \\
\text { es of } 16 S \\
\text { rRNA } \\
\text { gene } \\
\end{array}$ & $\begin{array}{l}\text { Accession } \\
\text { No. of 16S } \\
\text { rRNA gene }\end{array}$ & $\begin{array}{l}\text { Closely related validly } \\
\text { published species }\end{array}$ & $\begin{array}{l}\text { Sequence } \\
\text { similarity } \\
(\%) \text { of } 16 S \\
\text { rRNA gene }\end{array}$ \\
\hline NCCP-132 & Bacillus sp. & 1557 & AB562920 & $\begin{array}{l}\text { Bacillus pakistanensis } \\
\text { NCCP-168 } \\
\text { (AB618147) }\end{array}$ & 96.66 \\
\hline NCCP-133 & Bacillus sp. & 1477 & AB562921 & $\begin{array}{c}\text { Bacillus } \\
\text { oceanisediminis } \mathrm{H} 2^{\mathrm{T}} \\
(\mathrm{GQ292772)}\end{array}$ & 99.35 \\
\hline NCCP-134 & $\begin{array}{l}\text { Ornithinibacillus } \\
\text { sp. }\end{array}$ & 1538 & AB562922 & $\begin{array}{c}\text { Ornithinibacillus } \\
\text { contaminans } \text { CCUG } \\
53201^{\mathrm{T}} \text { (FN597064) }\end{array}$ & 96.41 \\
\hline NCCP-135 & $\begin{array}{l}\text { Oceanobacillus } \\
\text { sp. }\end{array}$ & 1499 & AB562923 & $\begin{array}{l}\text { Oceanobacillus } \\
\text { profundus CL-MP28 } \\
\text { (DQ386635) }\end{array}$ & 96.75 \\
\hline NCCP-136 & Bacillus sp. & 1436 & AB562924 & $\begin{array}{l}\text { Bacillus oryzaecorticis } \\
\mathrm{R} 1^{\mathrm{T}}(\mathrm{KF} 548480)\end{array}$ & 98.00 \\
\hline
\end{tabular}

\section{Phylogenetic Analysis of Identified Strains}

The strains NCCP-132, NCCP-133 and NCCP-136 belong to genus Bacillus based on 16S rRNA gene sequence data as depicted in the phylogenetic tree (Figure 2). Strain NCCP-132 showed $96.66 \%$ similarity with Bacillus pakistanensis NCCP-168 ${ }^{\mathrm{T}}$ (Table 1), whereas NCCP-133 and NCCP-136 have sequence similarity of $99.35 \%$ and $98.0 \%$ with Bacillus oceanisediminis $\mathrm{H} 2^{\mathrm{T}}$ and Bacillus oryzaecorticis $\mathrm{R} 1^{\mathrm{T}}$, respectively. Based on 16S rRNA gene sequence data, the strains NCCP-134 and NCCP-135 belonged to genera Ornithinibacillus and Oceanobacillus (Figure 3) and showed sequence similarity of $96.41 \%$ and $96.75 \%$ with Ornithinibacillus contaminans CCUG 53201 ${ }^{\mathrm{T}}$ (FN597064) and Oceanobacillus profundus CL-MP28 ${ }^{\mathrm{T}}$ (DQ386635), respectively. As the similarity with pre-identified species was less than $97 \%$, suggesting these two strains can be further studied taxonomically to delineate these strains as novel species. 


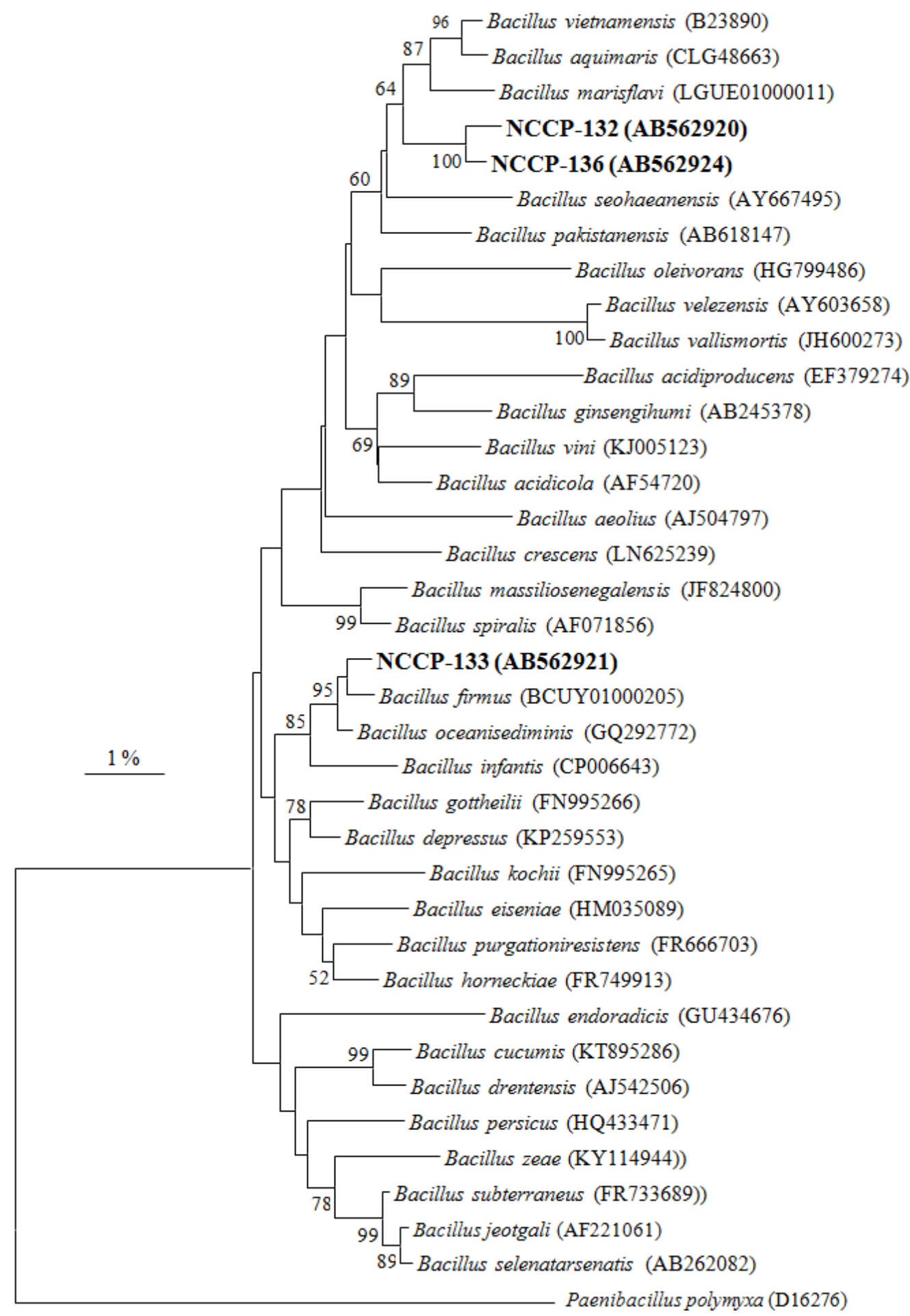

Figure 2. Phylogenetic tree showing inter-relationship of the strains NCCP-132, NCCP-133 and NCCP-136 with the most closely related Bacillus species inferred from sequences of $16 \mathrm{~S}$ rRNA gene. Data with gaps were removed during alignment for the construction of tree, which is rooted by using Paenibacillus polymyxa (D16276) as an out group. The tree was generated using MEGA software package based on comparison of approximately 1,240 nucleotides. Bootstrap values (only > $50 \%$ are shown), expressed as a percentage of 1,000 replications, are given at the branching points. The sequence of Bar, $1 \%$ sequence divergence. The accession number of each type strain is shown in parentheses. 


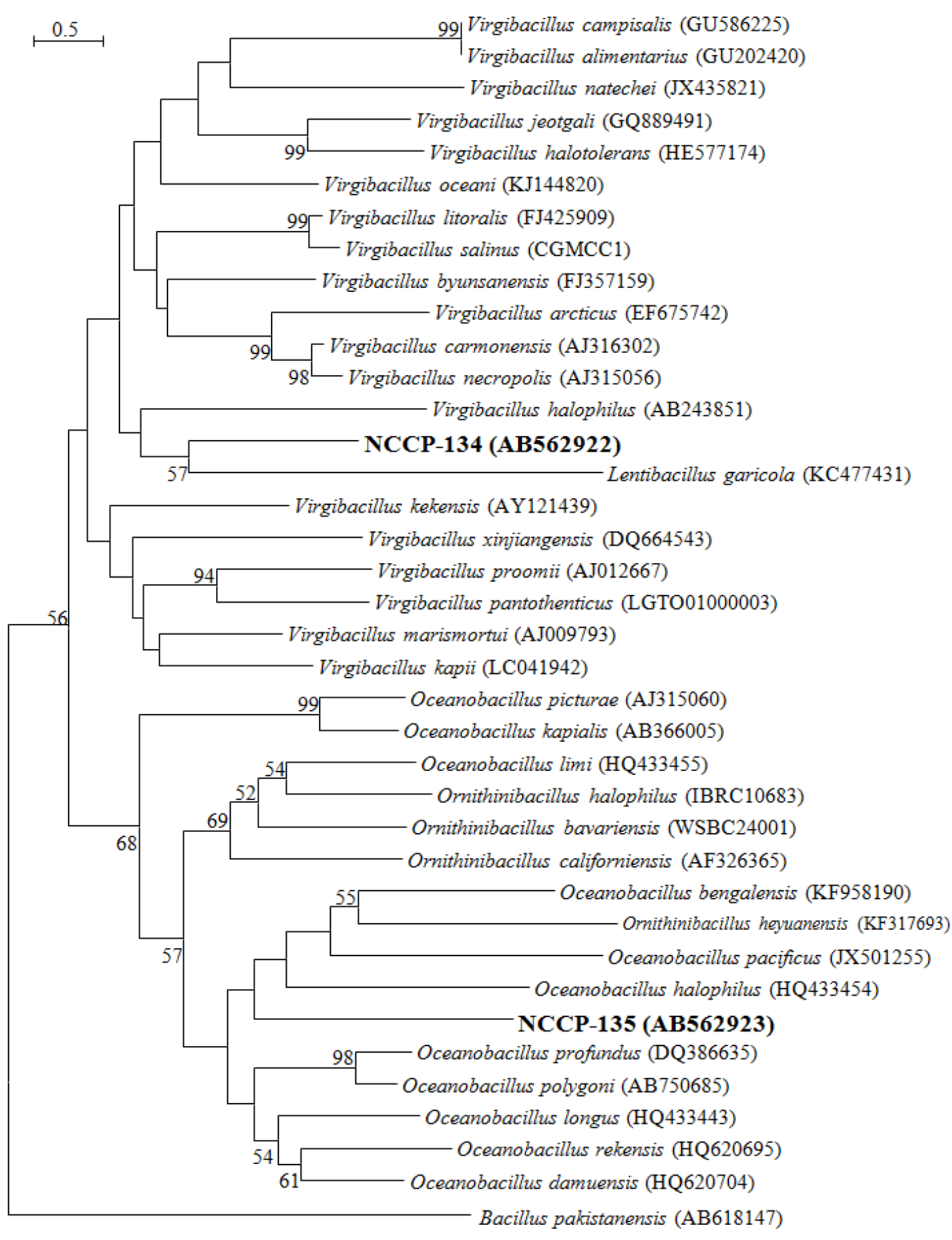

Figure 3. Phylogenetic tree showing inter-relationship of the strains NCCP-134 and 135 with the most closely related Oceanobacillus, Virgibacillus, and Lentibacillus species inferred from the sequences of $16 S$ rRNA gene. Data with gaps were removed during alignment for the construction of tree, which is rooted by using Bacillus pakistanensis (AB618147) as an out group. The tree was generated using the MEGA software package based on comparison of approximately 1,240 nucleotides. Bootstrap values (only > 50\% are shown), expressed as a percentage of 1,000 replications, are given at the branching points. The sequence of Bar, $0.5 \%$ sequence divergence. The accession number of each type strain is shown in parentheses. 
The $\mathrm{G}+\mathrm{C}$ content of the DNA of the type strain should be determined by high performance liquid chromatography (HPLC) and is recommended for the description of novel species, and essential for the description of new genera (Logan et al., 2009). As identical or highly similar 16S rRNA gene sequences do not guarantee species identity, DNA-DNA hybridization is essential in case of species description when 16S rRNA gene sequences of the novel strains show $<97 \%$ or less similarity with existing taxa. Several widely used methods do not allow the determination of thermal stability (expressed as $\Delta \mathrm{Tm}$ ) of the hybrid, but differences in $\Delta \mathrm{Tm}$ between the hybrid and the homologous duplex are important and can be decisive for taxonomic conclusions. Hence, determination of $\Delta \mathrm{Tm}$ is recommended (Logan et al., 2009).

Nucleic acid fingerprinting is also recommended because DNA fingerprinting methods provide information at the subspecies and strain level. Examples are amplified fragment-length polymorphism (AFLP) analysis, macrorestriction analysis after pulsedfield gel electrophoresis (PFGE), random amplified polymorphic DNA (RAPD) analysis, rep-PCR (repetitive element-primed PCR, directed to naturally occurring, highly conserved, repetitive DNA sequences, present in multiple copies in the genome), including REP-PCR (repetitive extragenic palindromic-PCR), ERIC-PCR (enterobacterial repetitive intergenic consensus sequences PCR), BOX-PCR (derived from the boxA element) and (GTG) 5 -PCR, and ribotyping (Logan et al., 2009). DNADNA hybridization study, together with DNA fingerprinting and 16S rRNA sequence analysis clearly demonstrate the strains to be novel or already identified and more work has to be done on the phenotypic and genotypic level.

\section{Colony Morphology of Bacterial Strains}

The isolated five bacterial strains were grown at $28{ }^{\circ} \mathrm{C}$ for 3 days on TSA medium containing $100 \mathrm{mM}$ boron concentration. Phase-contrast microscopy showed colony morphology of isolated strains. Gram staining of bacterial isolates was also performed (Table 2). Colonial pigmentation of the isolates included pale yellow, creamy and orange coloration. The colonies were round and punctiform in shape and circular in form. Colony surfaces were smooth and margins were entire. Colonies had raised, flat, and convex elevations. The colonies possessed moist and mucoid texture, whereas the opacity of colonies was found to be translucent and opaque.

Table 2. Colony morphology of bacterial strains observed 3 days after inoculation and incubation at $28{ }^{\circ} \mathrm{C}$. The medium used was Tryptic Soy Agar (TSA) containing $100 \mathrm{mM}$ boron.

\begin{tabular}{c|c|c|c|c|c}
\hline \multirow{2}{*}{ Characteristics } & \multicolumn{5}{|c}{ Bacterial Strains } \\
\cline { 2 - 6 } & NCCP-132 & NCCP-133 & NCCP-134 & NCCP-135 & NCCP-136 \\
\hline Color & Cream & Yellow & Cream & Yellow & Orange \\
Shape & Round & Round & Punctiform & Round & Punctiform \\
Form & Circular & Circular & Circular & Circular & Circular \\
Margin & Entire & Entire & Entire & Entire & Entire \\
Surface & Smooth & Smooth & Smooth & Smooth & Smooth \\
Elevation & Convex & Raised & Flat & Raised & Raised \\
Texture & Moist & Mucoid & Mucoid & Moist & Moist \\
Opacity & Translucent & Translucent & Translucent & Translucent & Opaque \\
Size & $2.5 \mathrm{~mm}$ & $1.5 \mathrm{~mm}$ & $0.5 \mathrm{~mm}$ & $1.0 \mathrm{~mm}$ & $1.0 \mathrm{~mm}$ \\
\hline
\end{tabular}




$$
-1219 \text { - }
$$

Phase-contrast microscopy at x1000 magnification is superior to bright-field microscopy of stained smears, including spore staining, and is much more convenient (Logan et al., 2009). Electron microscopy could be done to reveal additional morphological information like flagellation, and sporangial appearance could also be checked.

Optimization of growth conditions for all strains was carried out regarding $\mathrm{pH}$, temperature and $\mathrm{NaCl}$ tolerance (Table 3). The boron-tolerant bacterial strains were found to grow best at 7-9 $\mathrm{pH}, 16-37{ }^{\circ} \mathrm{C}$ temperature and $0-4 \%(\mathrm{v} / \mathrm{v}) \mathrm{NaCl}$ concentration. All bacterial isolates were oxidase and catalase positive as well as Gram-positive. Positive, negative, weakly positive, moderately positive, and strongly positive observations were recorded via tests of API ZYM and API 50CH kits (Table 4a, b).

Table 3. Physiological characteristics of boron tolerant isolated bacterial strains.

\begin{tabular}{c|c|c|c|c}
\hline $\begin{array}{c}\text { Bacterial } \\
\text { Strains }\end{array}$ & $\begin{array}{c}\text { Range of growth } \\
\text { at Boron } \\
\text { concentration } \\
\text { (Optimum) }\end{array}$ & $\begin{array}{c}\text { Range of growth } \\
\text { at NaCl } \\
\text { concentration } \\
\text { (Optimum) }\end{array}$ & $\begin{array}{c}\text { Range of } \\
\text { growth at pH } \\
\text { (Optimum) }\end{array}$ & $\begin{array}{c}\text { Range of growth at } \\
\text { Temperature } \\
\text { (Optimum) }\end{array}$ \\
\hline NCCP-132 & $0-450(100)$ & $0-3(0-2)$ & $7-8(7)$ & $10-45(37)$ \\
NCCP-133 & $0-450(100)$ & $0-5(0-4)$ & $7-9(8.5-9.0)$ & $10-45(28)$ \\
NCCP-134 & $0-450(100)$ & $0-14(0)$ & $7-8(8)$ & $10-37(37)$ \\
NCCP-135 & $0-450(100)$ & $0-14(1-2)$ & $5-9(8)$ & $10-37(28-37)$ \\
NCCP-136 & $0-200(100)$ & $0-7(0)$ & $7-9(8.5)$ & $10-45(28-37)$ \\
\hline
\end{tabular}

Table 4a. Biochemical results for enzymatic activities of the strains.

\begin{tabular}{|c|c|c|c|c|c|}
\hline \multirow[b]{2}{*}{ Biochemical Tests } & \multicolumn{5}{|c|}{ Bacterial Strains } \\
\hline & $\begin{array}{c}\text { NCCP- } \\
132 \\
\end{array}$ & $\begin{array}{c}\text { NCCP- } \\
133 \\
\end{array}$ & $\begin{array}{c}\text { NCCP- } \\
134 \\
\end{array}$ & $\begin{array}{c}\text { NCCP- } \\
135 \\
\end{array}$ & $\begin{array}{c}\text { NCCP } \\
136 \\
\end{array}$ \\
\hline Alkaline phosphatase & - & - & +++ & - & - \\
\hline Esterase (C4) & - & - & - & - & - \\
\hline Esterase Lipase (C8) & - & - & w+ & $w+$ & - \\
\hline Lipase (C14) & - & - & - & - & - \\
\hline Leucine arylamidase & $w+$ & - & - & $w+$ & - \\
\hline Valine arylamidase & w+ & - & _- & - & - \\
\hline Cystine arylamidase & $w+$ & $w+$ & $\mathrm{m}+$ & $\mathrm{m}+$ & w+ \\
\hline Trypsin & - & - & - & - & - \\
\hline$\alpha$-chymotrypsin & $w+$ & $w+$ & $\mathrm{m}+$ & $\mathrm{m}+$ & $\mathrm{w}+$ \\
\hline Acid phosphatase & - & - & + & - & _- \\
\hline Naphthol-AS-B1- & ++ & - & - & - & - \\
\hline$\alpha$-galactosidase & w+ & - & - & - & - \\
\hline$\beta$-galactosidase & $\mathrm{w}+$ & - & $\mathrm{m}+$ & - & - \\
\hline$\beta$-glucuronidase & - & - & - & - & - \\
\hline$\alpha$-glucosidase & $\mathrm{w}+$ & - & - & - & - \\
\hline$\beta$-glucosidase & w+ & - & - & - & - \\
\hline $\mathrm{N}$-acetyl- $\beta$-glucosaminidase & $w+$ & - & ++ & $\mathrm{w}+$ & - \\
\hline$\alpha$-mannosidase & $\mathrm{w}+$ & - & - & $\mathrm{w}+$ & - \\
\hline$\beta$-galactosidase & - & - & - & - & - \\
\hline Arginine dihydrolase & _- & _- & _- & _- & _- \\
\hline
\end{tabular}




\begin{tabular}{c|c|c|c|c|c}
\hline Lysine decarboxylase & - & - & - & - & - \\
Ornithine decarboxylase & - & - & - & - & - \\
Citrate utilization & - & - & - & - & - \\
Urease & - & - & - & - & - \\
Tryptophane deaminase & + & + & + & + & + \\
Gelatinase & - & - & - & + & + \\
$\alpha$-fucosidase & $\mathrm{w}+$ & - & - & - & - \\
\hline
\end{tabular}

+ positive, - negative, $\mathrm{w}+$ weakly positive, $\mathrm{m}+$ moderately positive, ++ strongly positive

Table 4b. Biochemical results for utilization of carbohydrates and other substrates.

\begin{tabular}{|c|c|c|c|c|c|}
\hline \multirow[b]{2}{*}{ Biochemical Tests } & \multicolumn{5}{|c|}{ Bacterial Strains } \\
\hline & $\begin{array}{c}\text { NCCP- } \\
132 \\
\end{array}$ & $\begin{array}{c}\text { NCCP- } \\
133 \\
\end{array}$ & $\begin{array}{c}\text { NCCP- } \\
134 \\
\end{array}$ & $\begin{array}{c}\text { NCCP- } \\
135 \\
\end{array}$ & $\begin{array}{c}\text { NCCP- } \\
136 \\
\end{array}$ \\
\hline Glycerol & - & - & $\mathrm{w}+$ & - & - \\
\hline Erythritol & - & - & - & - & - \\
\hline D-Arabinose & - & - & - & - & - \\
\hline L-Arabinose & - & - & $\mathrm{w}+$ & - & - \\
\hline D-Ribose & - & - & $w+$ & - & - \\
\hline D-Xylose & - & - & - & - & - \\
\hline L-Xylose & - & - & - & - & - \\
\hline D-Adonitol & - & - & - & - & - \\
\hline Methyl- $\beta$ D-Xylopyranoside & - & - & - & - & - \\
\hline D-Galactose & - & - & - & - & - \\
\hline D-Glucose & - & - & $\mathrm{w}+$ & - & - \\
\hline D-Fructose & - & _- & w+ & - & _- \\
\hline D-Mannose & - & - & $w+$ & - & - \\
\hline L-Sorbose & - & - & - & - & - \\
\hline L-Rhamnose & _- & - & - & - & - \\
\hline Dulcitol & - & - & - & - & - \\
\hline Inositol & - & - & - & - & - \\
\hline D-Mannitol & - & - & $\mathrm{w}+$ & - & - \\
\hline D-Sorbitol & - & - & $w+$ & - & - \\
\hline Methyl- $\alpha$-D-Mannopyranoside & - & - & - & - & - \\
\hline Methyl- $\alpha \mathrm{D}$-Glucopyranoside & - & - & - & - & - \\
\hline$N$-Acetyl Glucosamine & - & - & $w+$ & + & - \\
\hline Amygdalin & - & - & - & - & - \\
\hline Arbutin & - & - & - & - & - \\
\hline Esculin & - & _- & ++ & - & - \\
\hline Salicin & - & - & $\mathrm{w}+$ & - & - \\
\hline D-Cellobiose & - & - & $\mathrm{w}+$ & w+ & - \\
\hline D-Maltose & - & - & - & - & - \\
\hline D-Lactose & _ & - & _- & _ & _ \\
\hline
\end{tabular}




\begin{tabular}{|c|c|c|c|c|c|}
\hline D-Melibiose & - & - & + & - & - \\
\hline D-Saccharose & - & - & - & - & - \\
\hline D-Trehalose & - & - & - & - & - \\
\hline Innulin & - & - & - & - & - \\
\hline D-Melezitose & - & - & - & - & - \\
\hline D-Raffinose & - & - & - & - & - \\
\hline Amidon(Starch) & - & - & - & $\mathrm{w}+$ & - \\
\hline Glycogen & - & - & - & $\mathrm{w}+$ & - \\
\hline Xylitol & - & - & - & w+ & - \\
\hline Gentiobiose & - & - & - & - & - \\
\hline D-Turanose & - & - & - & - & - \\
\hline D-Lyxose & - & - & - & - & - \\
\hline D-Tagatose & - & - & $\mathrm{w}+$ & w+ & - \\
\hline D-Fucose & - & - & - & - & - \\
\hline L-Fucose & - & - & - & - & - \\
\hline D-Arabitol & - & - & $\mathrm{w}+$ & - & - \\
\hline L-Arabitol & - & - & $\mathrm{w}+$ & - & - \\
\hline Potassium gluconate & - & - & $\mathrm{w}+$ & - & - \\
\hline Potassium-2-ketogluconate & - & - & - & - & - \\
\hline Potassium-5-ketogluconate & + & - & - & $\mathrm{w}+$ & - \\
\hline $\mathrm{H}_{2} \mathrm{~S}$ production & - & - & - & - & - \\
\hline Indole production & - & - & - & - & - \\
\hline Acetoin production (Voges Proskauer) & - & - & - & - & - \\
\hline Fermentation/ oxidation of: & & & & & \\
\hline Glucose & - & - & - & - & - \\
\hline Mannitol & - & - & - & - & - \\
\hline Inositol & - & - & - & - & - \\
\hline Sorbitol & - & - & - & - & - \\
\hline Rhamnose & - & - & - & - & - \\
\hline Saccharose & - & - & - & - & - \\
\hline Melibiose & - & - & - & - & - \\
\hline Amygdalin & - & - & - & - & - \\
\hline Arabinose & - & - & - & - & - \\
\hline $\mathrm{NO}_{2}$ production & - & - & - & + & + \\
\hline $\mathrm{N}_{2}$ production & - & - & - & - & - \\
\hline
\end{tabular}

+ positive, - negative, $\mathrm{w}+$ weakly positive, ++ strongly positive

\section{Optimization of Conditions for Bacterial Growth and Biochemical Characterization}

Chemotaxonomic fingerprinting techniques applied to aerobic endospore-formers include fatty acid methyl ester (FAME) profiling, PAGE analysis of whole-cell proteins, polar lipid analysis, quinone content, cell-wall diamino acid content, pyrolysis mass spectrometry, Fourier-transform infrared spectroscopy, Raman spectroscopy and matrix- 
assisted laser desorption/ionization-time-of-flight (MALDI-TOF) mass spectrometry. Fatty acid profiles are very useful in descriptions of new taxa, and it is recommended that the fatty acid profile should be available and the minor compounds that are characteristics of a novel taxon should be stated in the description (Logan et al., 2009).

\section{Description of NCCP-132 and NCCP-136}

Phylogenetic analysis revealed that NCCP-132 and NCCP-136 belong to the Bacillus genus, and are similar to B. marisflavi, B. aquimaris and B. vietnamensis, based on comparison of $16 \mathrm{~S}$ rRNA gene sequence. On TSA medium, colonies of NCCP-132 are cream in colour, round, circular, smooth, having entire margins, having convex surface, moist, translucent and $2.5 \mathrm{~mm}$ in size after 3 days at $28{ }^{\circ} \mathrm{C}$. Cells are gram-positive, catalase-positive and oxidase-positive. In API ZYM gallery, alkaline phosphatase, esterase, esterase lipase, lipase, trypsin, acid phosphatase and $\beta$-glucuronidase tests are negative. Leucine arylamidase, valine arylamidase, cystine arylamidase, $\alpha-$ chymotrypsin, $\alpha$-galactosidase, $\beta$-galactosidase, $\alpha$-glucosidase, $\beta$-glucosidase, $\mathrm{N}$-acetyl$\beta$-glucosaminidase, $\alpha$-mannosidase, $\alpha$-fucosidase tests are weakly positive. NaphtholAS-B1-phosphohydrolase test is strongly positive. In API 50CH gallery, glycerol, erythritol, D-arabinose, L-arabinose, D-ribose, D-xylose, D-adonitol, methyl- $\beta \mathrm{D}$ xylopyranoside, D-galactose, D-glucose, D-fructose, D-mannose, L-sorbose, Lrhamnose, dulcitol, inositol, D-mannitol, D-sorbitol, methyl- $\alpha \mathrm{D}$-mannopyranoside, methyl- $\alpha \mathrm{D}$-glucopyranoside, $\mathrm{N}$-acetylglucosamine, amygdalin, arbutin, esculin, salicin, D-cellobiose, D-maltose, D-lactose, D-melibiose, D-saccharose, D-trehalose, inulin, Dmelezitose, D-raffinose, amidon, glycogen, xylitol, gentiobiose, D-turanose, D-lyxose, D-tagatose, D-fucose, L-fucose, D-arabitol, L-arabitol, potassium gluconate, potassium2-ketogluconate tests are negative. Potassium-5-ketogluconate test is positive. Optimum boron concentration needed for growth is $0 \mathrm{mM}$ and boron range for growth is $0-450$ $\mathrm{mM}$. Optimum growth $\mathrm{pH}$ is 7.0, thus, neutrophilic. $\mathrm{pH}$ range for growth is 7.0-8.0. Optimum growth temperature is $37^{\circ} \mathrm{C}$, thus, mesophilic. The temperature range for growth is $10-45^{\circ} \mathrm{C}$. Optimum $\mathrm{NaCl}$ concentration needed for growth is $0-2 \%$, thus, slightly halotolerant. The growth range for $\mathrm{NaCl}$ concentration is $0-3 \%$.

On TSA medium, colonies of NCCP-136 are orange in colour, punctiform, circular, smooth, having entire margins, having raised surface, moist, opaque and $1.0 \mathrm{~mm}$ in size after 3 days at $28^{\circ} \mathrm{C}$. Cells are gram-positive, catalase-positive and oxidase-positive. In API ZYM gallery, alkaline phosphatase, esterase, esterase lipase, lipase, trypsin, acid phosphatase, leucine arylamidase, $\alpha$-galactosidase, $\beta$-galactosidase, naphthol-AS-B1phosphohydrolase, $\alpha$-mannosidase, $\alpha$-fucosidase, $N$-acetyl- $\beta$-glucosaminidase, $\alpha$ glucosidase, $\beta$-glucosidase and $\beta$-glucuronidase tests are negative. Valine arylamidase, cystine arylamidase, $\alpha$-chymotrypsin tests are weakly positive. In API 50CH gallery, glycerol, erythritol, D-arabinose, L-arabinose, D-ribose, D-xylose, D-adonitol, methyl$\beta \mathrm{D}$-xylopyranoside, D-galactose, D-glucose, D-fructose, D-mannose, L-sorbose, Lrhamnose, dulcitol, inositol, D-mannitol, D-sorbitol, methyl- $\alpha$ D-mannopyranoside, methyl- $\alpha \mathrm{D}$-glucopyranoside, $\mathrm{N}$-acetylglucosamine, amygdalin, arbutin, esculin, salicin, D-cellobiose, D-maltose, D-lactose, D-melibiose, D-saccharose, D-trehalose, inulin, Dmelezitose, D-raffinose, amidon, glycogen, xylitol, gentiobiose, D-turanose, D-lyxose, D-tagatose, D-fucose, L-fucose, D-arabitol, L-arabitol, potassium gluconate, potassium2-ketogluconate and potassium-5-ketogluconate tests are negative. Optimum boron concentration needed for growth is $0 \mathrm{mM}$ and boron range for growth is $0-200 \mathrm{mM}$. Optimum growth $\mathrm{pH}$ is 8.5 , thus, alkaliphilic. $\mathrm{pH}$ range for growth is 7.0-9.0. Optimum 
growth temperature is $28-37^{\circ} \mathrm{C}$, thus, mesophilic. The temperature range for growth is $10-45^{\circ} \mathrm{C}$. Optimum $\mathrm{NaCl}$ concentration needed for growth is $0 \%$, thus, non-halotolerant. The growth range for $\mathrm{NaCl}$ concentration is $0-7 \%$.

\section{Description of NCCP-133}

Phylogenetic analysis revealed that NCCP-133 belongs to the Bacillus genus, and is similar to $B$. firmus, based on comparison of $16 \mathrm{~S}$ rRNA gene sequence. On TSA medium, colonies of NCCP-133 are yellow in colour, round, circular, smooth, having entire margins, having raised surface, mucoid, translucent and $1.5 \mathrm{~mm}$ in size after 3 days at $28^{\circ} \mathrm{C}$. Cells are gram-positive, catalase-positive and oxidase-positive. In API ZYM gallery, alkaline phosphatase, esterase, esterase lipase, lipase, trypsin, acid phosphatase, leucine arylamidase, valine arylamidase, $\alpha$-galactosidase, $\beta$-galactosidase, naphthol-AS-B1-phosphohydrolase, $\quad \alpha$-mannosidase, $\quad \alpha$-fucosidase, $\quad N$-acetyl- $\beta$ glucosaminidase, $\alpha$-glucosidase, $\beta$-glucosidase and $\beta$-glucuronidase tests are negative. Cystine arylamidase and $\alpha$-chymotrypsin tests are weakly positive. In API $50 \mathrm{CH}$ gallery, glycerol, erythritol, D-arabinose, L-arabinose, D-ribose, D-xylose, D-adonitol, methyl- $\beta \mathrm{D}$-xylopyranoside, D-galactose, D-glucose, D-fructose, D-mannose, L-sorbose, L-rhamnose, dulcitol, inositol, D-mannitol, D-sorbitol, methyl- $\alpha$ D-mannopyranoside, methyl- $\alpha \mathrm{D}$-glucopyranoside, $\mathrm{N}$-acetylglucosamine, amygdalin, arbutin, esculin, salicin, D-cellobiose, D-maltose, D-lactose, D-melibiose, D-saccharose, D-trehalose, inulin, Dmelezitose, D-raffinose, amidon, glycogen, xylitol, gentiobiose, D-turanose, D-lyxose, D-tagatose, D-fucose, L-fucose, D-arabitol, L-arabitol, potassium gluconate, potassium2-ketogluconate and potassium-5-ketogluconate tests are negative. Boron range for growth is $0-450 \mathrm{mM}$. Optimum $\mathrm{pH}$ is $8.5-9.0$, thus, alkaliphilic. $\mathrm{pH}$ range for growth is 7.0-9.0. Optimum temperature is $16-32^{\circ} \mathrm{C}$, thus, psychrophilic and mesophilic. The temperature range for growth is $10-45^{\circ} \mathrm{C}$. Optimum $\mathrm{NaCl}$ concentration is $0-4 \%$, thus moderately halotolerant. The growth range for $\mathrm{NaCl}$ concentration is $0-5 \%$.

\section{Description of NCCP-134}

Phylogenetic analysis revealed that NCCP-134 belongs to Lentibacillus genus, and is similar to L. garicola, based on comparison of $16 \mathrm{~S}$ rRNA gene sequence. On TSA medium, colonies of NCCP-134 are cream in colour, punctiform, circular, smooth, having entire margins, having flat surface, mucoid, translucent and $0.5 \mathrm{~mm}$ in size after 3 days at $28^{\circ} \mathrm{C}$. Cells are gram-positive, catalase-positive and oxidase-positive. In API ZYM gallery, esterase, lipase, trypsin, leucine arylamidase, valine arylamidase, naphthol-AS-B1-phosphohydrolase, $\alpha$-galactosidase, $\alpha$-glucosidase, $\beta$-glucosidase, $\alpha$ mannosidase, $\alpha$-fucosidase and $\beta$-glucuronidase tests are negative. Alkaline phosphatase and $\mathrm{N}$-acetyl- $\beta$ - glucosaminidase tests are strongly positive. Esterase lipase test is weakly positive. Cystine arylamidase, $\alpha$-chymotrypsin and $\beta$-galactosidase tests are moderately positive. In API 50CH gallery, erythritol, D-arabinose, D-xylose, L-xylose, D-adonitol, methyl- $\beta \mathrm{D}$-xylopyranoside, D-galactose, L-sorbose, L-rhamnose, dulcitol, inositol, methyl- $\alpha \mathrm{D}$-mannopyranoside, methyl- $\alpha \mathrm{D}$-glucopyranoside, amygdalin, arbutin, D-maltose, D-lactose, D-saccharose, D-trehalose, inulin, D-melezitose, D-raffinose, amidon, glycogen, xylitol, gentiobiose, D-turanose, D-lyxose, D-fucose, L-fucose, potassium-2-ketogluconate tests are negative. Glycerol, L-arabinose, D-ribose, Dglucose, D-fructose, D-mannose, D-mannitol, D-sorbitol, N-acetylglucosamine, salicin, D-cellobiose, D-tagatose, D-arabitol, L-arabitol and potassium gluconate tests are weakly positive. D-melibiose test is positive. Esculin test is strongly positive. Optimum 
boron concentration needed for growth is $0 \mathrm{mM}$ and boron range for growth is 0$450 \mathrm{mM}$. Optimum $\mathrm{pH}$ is 8.0, thus, alkaliphilic. $\mathrm{pH}$ range for growth is 7.0-8.0. Optimum temperature is $37^{\circ} \mathrm{C}$, thus, mesophilic. The temperature range for growth is $10-37^{\circ} \mathrm{C}$. Optimum $\mathrm{NaCl}$ concentration is $0 \%$, thus, non-halotolerant. The growth range for $\mathrm{NaCl}$ concentration is $0-14 \%$.

\section{Description of NCCP-135}

Phylogenetic analysis revealed that NCCP-135 belongs to the Oceanobacillus genus, and is similar to $O$. profundus, based on comparison of $16 \mathrm{~S}$ rRNA gene sequence. On TSA medium, colonies of NCCP-135 are yellow in colour, round, circular, smooth, having entire margins, having raised surface, moist, translucent and $1.0 \mathrm{~mm}$ in size after 3 days at $28^{\circ} \mathrm{C}$. Cells are gram-positive, catalase-positive and oxidase-positive. In API ZYM gallery, alkaline phosphatase, esterase, lipase, acid phosphatase, trypsin, valine arylamidase, naphthol-AS-B1-phosphohydrolase, $\alpha$-galactosidase, $\alpha$-glucosidase, $\beta$ glucosidase, $\alpha$-fucosidase and $\beta$-glucuronidase, $\beta$-galactosidase tests are negative. Esterase lipase and leucine arylamidase, $\alpha$-mannosidase, $\mathrm{N}$-acetyl- $\beta$-glucosaminidase tests are weakly positive. Cystine arylamidase, $\alpha$-chymotrypsin and tests are moderately positive. In API 50CH gallery, glycerol, L-arabinose, D-ribose, D-glucose, D-fructose, D-mannose, D-mannitol, D-sorbitol, esculin, salicin, D-melibiose, erythritol, D-arabitol, L-arabitol, potassium gluconate, D-arabinose, D-xylose, D-adonitol, methyl- $\beta \mathrm{D}$ xylopyranoside, D-galactose, L-sorbose, L-rhamnose, dulcitol, inositol, methyl- $\alpha \mathrm{D}$ mannopyranoside, methyl- $\alpha \mathrm{D}$-glucopyranoside, amygdalin, arbutin, D-maltose, Dlactose, D-saccharose, D-trehalose, inulin, D-melezitose, D-raffinose, gentiobiose, Dturanose, D-lyxose, D-fucose, L-fucose, L-xylose potassium-2-ketogluconate tests are negative. Potassium-5-ketogluconate, D-cellobiose, D-tagatose, amidon, glycogen, xylitol and tests are weakly positive. $\mathrm{N}$-acetylglucosamine test is positive. Optimum boron concentration needed for growth is $0-50 \mathrm{mM}$ and boron range for growth is 0 $450 \mathrm{mM}$. Optimum $\mathrm{pH}$ is 8.0, thus, alkaliphilic. $\mathrm{pH}$ range for growth is 5.0-9.0. Optimum temperature is $37^{\circ} \mathrm{C}$, thus, mesophilic. The temperature range for growth is $10-37^{\circ} \mathrm{C}$. Optimum $\mathrm{NaCl}$ concentration is $1-2 \%$, but its tolerance to $\mathrm{NaCl}$ ranges $0-14 \%$, thus, slightly halotolerant.

\section{Conclusion}

Bacterial isolates having high biological diversity were found from the sewage samples taken from different sites of sewage treatment pond. Biological diversity is evident from the data depicting morphology of these isolates. As phenotypic characterization was not enough for microbial identification so different factors like $\mathrm{pH}$, temperature and $\mathrm{NaCl}$ were optimized for growing boron-tolerant bacteria. Furthermore, biochemical testing showed different biochemical properties of bacterial isolates. However, the accurate taxonomic position of bacterial strains was confirmed by the conventional method for microbial identification, i.e., phylogenetic analysis using comparative sequence analysis of $16 \mathrm{~S}$ rRNA gene. Out of the five bacterial isolates, four were highly boron-tolerant and one was moderately boron-tolerant strain. NCCP133 and NCCP-136 were found to be pre-identified strains as these shared >97\% similarity of 16S rRNA gene sequence with their closest relatives. NCCP-132 (Bacillus sp.), NCCP-134 (Lentibacillus sp.) and NCCP-135 (Oceanobacillus sp.) were found to be novel species based on phylogenetic analysis, however further taxonomic 
characterization particularly chemotaxonomic profiling is required to meet the minimum standards for delineation of these isolates as a novel species.

The present study is the first study from Pakistan exploring a new aspect of extremophiles. Finding out the boron tolerance and essentiality level for novel bacterial strains would provide a genetic resource to identify the genes responsible for mechanisms of boron-tolerance and boron-requirement in bacteria. Gene identification would help in the successful management of boron in agriculture and such genes might be useful for cloning in other organisms especially the crop species that are grown on high boron soils. Moreover, it will provide information to study the biochemistry of boron in living cells.

Acknowledgements. This work was supported by financial assistance from PSDP funded Project Research for Agricultural Development Project under a sub-project (Grant No. CS-55/RADP/PARC to Iftikhar Ahmed) entitled "Establishment of Microbial Bio-Resource Laboratories: National Culture Collection of Pakistan (NCCP)" from Pakistan Agricultural Research Council, Islamabad, Pakistan.

\section{REFERENCES}

[1] Ahmed, I., Fujiwara, T. (2010): Mechanism of boron tolerance in soil bacteria. Canadian Journal of Microbiology 56: 22-26.

[2] Ahmed, I., Yokota, A., Fujiwara T. (2007a): A novel highly boron-tolerant bacterium, Bacillus boroniphilus sp. nov., isolated from soil, that requires boron for its growth. Extremophiles 11: 217-224.

[3] Ahmed, I., Yokota, A., Fujiwara, T. (2007b): Gracilibacillus boraciitolerans sp. nov., a novel highly boron-tolerant and moderately haloterant bacterium isolated from soil. International Journal of Systematic and Evolutionary Microbiology 57: 796-802.

[4] Ahmed, I., Yokota, A., Fujiwara, T. (2007c): Chimaereicella boritolerans sp. nov., a novel boron-tolerant and alkaliphilic bacterium of the family "Flavobacteriaceae", isolated from soil. - International Journal of Systematic and Evolutionary Microbiology 57: 986-992.

[5] Ahmed, I., Yokota, A., Fujiwara, T. (2007d): Proposal of Lysinibacillus boronitolerans gen. nov. sp. nov., and transfer of Bacillus fusiformis to Lysinibacillus fusiformis comb. nov. and Bacillus sphaericus to Lysinibacillus sphaericus comb. nov. - International Journal of Systematic and Evolutionary Microbiology 57: 1117-1125.

[6] Cochran, D. G. (1995): Toxic effects of boric acid on the German cockroach. Experientia 51: 561-563.

[7] Çöl, M., Çöl, C. (2003): Environmental boron contamination in waters of the Hisarcik area in the Kutahya Province of Turkey. - Food and Chemical Toxicology 41: 14171420 .

[8] Cowan, S. T., Steel, K. J. (2004): Manual for identification of medical bacteria. 3rd Edition. - Cambridge University Press, 50-140.

[9] Goldbach, H. E, Huang, L., Monika, A. W. (2010): Boron functions in plants and animals: Recent advances in boron research and open questions. - Advances in Plant and Animal Boron Nutrition, 3-25.

[10] Logan, N. A., Berge, O., Bishop, A. H., Busse, H. J., De Vos, P., Fritze, D., Heyndrickx, M., Kampfer, P., Rabinovitch, L., Salkinoja-Salonen, M. S., Seldin, L., Ventosa, A. (2009): Proposed minimal standards for describing new taxa of aerobic, endosporeforming bacteria. - International Journal of Systematic and Evolutionary Microbiology 59: 2114-2121. 
[11] Miwa, H., Ahmed, I., Yokota, A, Fujiwara, T. (2009): Lysinibacillus parviboronicapiens sp. nov., a low-boron-containing bacterium isolated from soil. - International Journal of Systematic and Evolutionary Microbiology 59 (6): 1427-1432.

[12] Miwa, H., Ahmed, I., Yoon, J., Yokota, A., Fujiwara, T. (2008): Variovorax boronicumulans sp. nov., a boron-accumulating bacterium isolated from soil. International Journal of Systematic and Evolutionary Microbiology 58 (1): 286-289.

[13] Nable, R. O., Bañuelos, G. S., Paull, J. G. (1997): Boron toxicity. - Plant and Soil 193: 181-198.

[14] Nielsen, F. H. (2004): Boron. - In: Merian, E., Anke, M., Ihnat, M., Stoeppler, M. (eds.) Elements and their Compounds in the Environment, 2nd edn. - Weinheim:,Wiley-VCH. 1251-1260.

[15] Otero, L., Palacio, V., Mendez, F. J., Vazquez, F. (2002): Boric acid susceptibility testing of non- C. albicans Candida and Saccharomyces cerevisiae: comparison of three methods. - Medical Mycology 40: 319-322.

[16] Rampelotto, P. H. (2010): Resistance of microorganisms to extreme environmental conditions and its contribution to astrobiology. - Sustainability 2: 1602-1623.

[17] Saleem, M., Khanif, Y. M., Ishak, F., Samsuri, A. W., Hafeez, B. (2011): Importance of boron for agriculture productivity: a review. - International Research Journal of Agricultural Science and Soil Science 1 (8): 293-300.

[18] Stanier, R. Y, Palleroni, N. J., Doudoroff, M. (1966): The aerobic pseudomonads: a taxonomic study. - Journal of General Microbiology 43, 159-271.

[19] Swate, T. E., Weed, J. C. (1974): Boric acid treatment of vulvovaginal candidiasis. Obstetrics and Gynecology 43: 893-895. 